https://doi.org/10.18485/iipe_postkovid.2021.ch10

\title{
PREUSMERAVANJE EKONOMSKE POLITIKE EVROPSKE UNIJE NAKON PANDEMIJE KOVID 19
}

\begin{abstract}
Duško DIMITRIJEVIĆ ${ }^{1}$
Apstrakt: Pandemija Kovid 19 pokrenula je fundamentalna pitanja o legitimitetu i održivosti aktuelnog ekonomskog poretka Evropske unije. Ovo tim pre, jer je zdravstvena kriza dovela do značajnih ekonomskih poremećaja koji se manifestuju u globalnim lancima snabdevanja, u destabilizaciji finansijskih tržišta i u ogromnim gubicima u ključnim sektorima industrijske proizvodnje i uslužnih delatnosti. Recesijski šok doveo je do pada BDP-a i do uvećanja javnog duga u znatnom broju država članica. Negativni pandemijski efekti postali su vidljiviji i na tržištu kapitala gde je Evropska unija, u svrhu zaštite sopstvenog javnog poretka i bezbednosti, uvela ciljane protekcionističke mere ograničavanja priliva stranih direktnih investicija iz trećih zemalja. Kako su, uz međunarodnu trgovinu, i strane direktne investicije jedna od ključnih determinanti razvoja evropske privrede i regionalnih integracija, sasvim je logično postaviti pitanje revitalizacije evropske privrede u postpandemijskom periodu. Na osnovu predmetne studije proizilazi da će za oporavak evropske privrede države članice morati da preduzimaju solidarne i koordinirane akcije koje uključuju ispunjavanje ciljeva i zadataka predviđenih u strateškim inicijativama „Evropskog zelenog dogovora" (European Green Deal) i „Sledeće generacije Evropske unije“ (Next Generation EU). Prema navedenim strateškim aktima, koji predviđaju program oporavka Evropske unije nakon pandemije Kovid 19, države članice će uz pomoć niza političkih i pravnih instrumenata, ekonomskih mehanizama i široko postavljenog finansijskog plana nastojati da postignu razvojne ciljeve preusmeravanja ekonomskih politika u pravcu uvođenja novih, efikasnijih, održivijih i legitimnijih modela ekonomskog razvoja koji će voditi više računa o klimatskim promenama i zaštiti životne sredine, kako bi se
\end{abstract}

\footnotetext{
${ }^{1}$ Naučni savetnik, Institut za međunarodnu politiku i privredu, Beograd. E-mail: dimitrijevicd@diplomacy.bg.ac.rs.

Rad je nastao u okviru naučnoistraživačkog projekta: „Srbija i izazovi u međunarodnim odnosima 2021. godine", koji finansira Ministarstvo prosvete, nauke i tehnološkog razvoja Republike Srbije, a realizuje Institut za međunarodnu politiku i privredu tokom 2021. godine.
} 
u perspektivi uspostavilo socijalno pravedno, ekološki održivo i ekonomski stabilno, integrisano i prosperitetno evropsko društvo „zelene i digitalne“ ekonomije.

Ključne reči: EU, pandemija, ekonomska kriza, Evropski zeleni dogovor

\section{Uvod}

Od početka 2020. godine veći deo sveta pogođen je pandemijom Kovid 19 koja svojim negativnim i višedimenzionalnim „domino efektima“ preti da ugrozi glavne osobenosti postojećeg života na Zemlji, uključujući i celokupan svetski ekonomski poredak. Izazivajući šok neslućenih razmera, pandemija Kovid 19 dovela je do ozbiljnih poremećaja u ekonomskim tokovima mnogih država. Prema podacima Međunarodnog monetarnog fonda, u 2020. godini došlo je do pada svetskog BDPa za 3,5 procenata, što je dovelo do najdublje ekonomske krize još od Drugog svetskog rata. ${ }^{2}$ Globalna finansijska kriza iz 2009. godine, kada je svetska proizvodnja pala za 0,1 odsto, u tom smislu nije uporediva sa izazovima koje sa sobom nosi aktuelna ekonomska kriza uzrokovana „velikim zaključavanjem" (Great Lockdown), usled pandemije Kovid 19. ${ }^{3}$ Samo na području Evropske unije, gde je u drugom kvartalu 2020. godine zabeležen pad BDP-a od 15\%, nagoveštavaju se ozbiljne ekonomske posledice čiji se negativni trend može nastaviti i u naredenim godinama. Početne prognoze o mogućem ekonomskom oporavku stoga nisu optimistične, mada ukazuju da bi sa efikasnijom kontrolom infekcije i uvođenjem ravnomernije i nediskriminatorske vakcinacije, bilo moguće ubrzati ekonomsku revitalizaciju i privredni oporavak. Iz dosadašnje prakse proizilazi da se povećana efikasnost zdravstvene zaštite može postići uz primenu efektivnih mera ekonomske politke koje mogu pomoći i da se negativni efekti ekonomske krize ne prelivaju u nerazvijene zemlje i regione, što bi se negativno odrazilo i na međunarodni ekonomski poredak u celini. Tim pre, jer prema aktuelnim prognozama proizilazi da bi negativni efekti ekonomske krize mogli nadoći sa zakašnjenjem usled ekspanzionistički vođene fiskalne politike, ili usled enormnog rasta javnog duga koji bi značajno usporio oporavak svetske privrede, ako ga ne bi i zaustavio za izvesno vreme. ${ }^{4}$ Pomenuta

\footnotetext{
${ }^{2}$ World Economic Outlook Reports, International Monetary Fund, January 2021.

${ }^{3}$ Mikaela Gavas, Samuel Pleeck, "Global Trends in 2021: How COVID-19 is Transforming International Development", Center for Global Development Note, March 2021.

${ }^{4} \mathrm{U}$ akteuelnim debatama povodom ovog pitanja smatra se da će rešavanje pitanja javnog duga zemlja u razvoju obuhvatati transparentne i kontinuirane pregovore oko iznalaženja
} 
mogućnost predstavlja realni izazov ne samo za socijalnu koheziju svake pogođene zemlje, već i za njihovu političku i ekonomsku stabilnost. Uzimajući još u obzir da je pandemija Kovid 19 imala za posledicu i enorman pad međunarodne trgovine i direktnih stranih investicija, onda je jasno zašto je Evropska unija kao vodeća supranacionalna ekonomska zajednica u svetu pristupila redefinisanju postojeće ekonomske politike s namerom da iznađe najefikasnije puteve za prevazilaženje akteuelne ekonomske krize. Ovakav pristup predstavlja odgovor Evropske unije na međunarodni izazov, prozrokovan ne samo pandemijom već i strukturalnim slabostima a čija rešenja se moraju tražiti kroz multilateralne mehanizme međunarodne zajednice $u$ skladu sa globalnom agendom za budućnost sveta. ${ }^{5}$

Jedno od ključnih pitanja u tom pogledu tiče se modernizacije sistema međunarodne trgovine. Budući da će brzina njegovog prestrukturiranja zavisiti od tehnološke transformacije proizvodnih ciklusa koji su locirani u različitim državama unutar i van Evropske unije, tj. od promena u globalnim lanacima vrednosti (Global Value Chains), pitanje modernizacije međunarodnog trgovinskog sistema ostaće direktno vezano za pitanje rešavanja svetske ekonomske krize. Kako se na području Evropske unije značajnije promene u lancima vrednosti ne mogu očekivati tako brzo, već tek sa saniranjem dosadašnjih negativnih posledica, tokovi modernizacije sistema međunarodne trgovine zavisiće od realizacije usvojenih ekonomskih mera. U tom smislu, Evropska unija namerava da primeni model otvorene strateške autonomije, koja

adekvatnog pristupa međunarodnoj likvidnosti. Tamo gde javni dug ne bi bio održiv, dužničke zemlje bi morale blisko sarađivati sa poveriocima na njihovom restrukturiranju u skladu sa Zajedničkim okvirom koji je dogovoren od strane grupacije G20 i Pariskog kluba. Videti: "Common Framework for Debt Treatments beyond the DSSI", Paris Club, Internet: https://clubdeparis.org/sites/default/files/annex_common_framework_for_debt_treatme nts_beyond_the_dssi.pdf, 01/07/2021.

${ }^{5}$ Evropska unija pokrenula je 8. aprila 2020. godine inicijativu „Tim Evropa“ (Team Europe), sa zadatkom pružanja brze i ciljane podrške partnerima koji se suoče sa pandemijom Kovid 19. Ovaj Tim kombinuje resurse Evropske unije, njenih država članica i finansijskih institucija, posebno Evropske investicione banke i Evropske banke za obnovu i razvoj, kao i drugih međunarodnih finansijskih institucija, u sadejstvu sa Ujedinjenim nacijama, G7 i G20, kako bi podržao zdravstvene, humanitarne, ekonomske i socijalne potrebe partnerskih država u svetu. Do sada je prikupljeno ukupno 40,5 milijardi evra, s tim da je već uloženo oko 26 milijardi evra u 130 zemalja sveta. Videti: "EU's international solidarity during the COVID-19 pandemic", Europen Council, Council of the EU, 25 May 2021, Internet: https://www. consilium.europa.eu/en/policies/coronavirus/global-solidarity/, 01/07/2021. 
bi dovela do osnaženja valutne stabilnosti i revizije postojeće trgovinske politike kojom bi se osigurala diverzifikacija i jačanje globalnih lanaca snabdevanja neophodnih za zaštitu od potencijalnih i budućih ekonomskih kriza. Ovakvim pristupom Evropska unija želi da utiče na oblikovanje novog sistema globalnog upravljanja (Global Governance) u ekonomskoj sferi, što ne može proći bez reforme Svetske trgovinske organizacije i osnaženja sistema ekonomske bezbednosti od nelojalnih trgovinskih praksi i zloupotreba. U cilju jačanja svojih strateških kapaciteta i izgradnje strateških lanaca vrednosti, Evropska unija je inicirala uspostavljanje mehanizama zaštite od pomenutih bezbednosnih rizika. Evropska unija je sledstveno uvela sistem nadzora stranih direktnih investicija u stratešku imovinu, infrastrukturu i tehnologije. ${ }^{6} \mathrm{~S}$ obzirom na to da su strane direktne investicije važan izvor ekonomskog rasta, zapošljavanja i inovacija i da predstavljaju ključni faktor socijalnog i ekonomskog razvoja država članica, Evropska unija je smatrala da je uvođenje ovakvih mera sasvim opravdano, jer se nelojalnim stranim direktnim investicijama narušava njihov javni poredak i bezbednost. Utoliko pre, jer je Evropska unija u periodu pre izbijanja pandemije Kovid 19, predstavljala glavnog investitora i najznačajniju destinaciju za strane investicije u svetu. Širenjem pandemije došlo je do poremećaja u globalnim lancima snabdevanja, do destabilizacije finansijskih tržišta, a potom i do i negativnih efekata stranih investicija nastalih preuzimanjem imovine, infrastrukture i tehnolologija u strateški važnim sektorima evropske privrede. Da bi izbegla veći recesijski udar od tzv. predatorskog kapitala, Evropska unija je morala odlučno reagovati u cilju normalizacije i očuvanja funkcionisanja jedinstvenog evropskog tržišta. Pritom, nije izgubila iz vida vitalni značaj ovog tržišta za održivost privreda država članica, pogotovo ako se uzme u obzir da su neke od država ostvarivale čak 70 procenata izvoza upravo unutar tržišta Evropske unije. $^{7}$

\footnotetext{
6 "Regulation (EU) 2019/452 of the European Parliament and of the Council of 19 March 2019 establishing a framework for the screening of foreign direct investments into the Union", OJ L 79, 21 March, 2019.

${ }^{7}$ S obzirom na to da kontrola investicija povlači odgovarajuća odstupanja od uobičajene trgovinske prakse, njeno sprovođenje mora biti izbalansirano između nediskriminatorskog i predvidljivog poslovnog okruženja i fleksibilnog i transparentno uspostavljenog sistema kontrole. Videti: Duško Dimitrijević, „Uredba Evropskog parlamenta i Saveta o uspostavljanju okvira za proveru stranih direktnih investicija u Evropskoj uniji", Evropsko zakonodavstvo, 2019, vol. 18, br. 68, str. 7-25.
} 
Preusmeravanje evropske ekonomske politike u uslovima ekonomske i zdravstvene krize stoga zahteva obezbeđenje pravilnog funkcionisanja evropskog tržišta, na kome će politika tržišnog takmičenja biti od ključne važnost za osiguranje jednakih uslova privrednog poslovanja. Održavanje kontinuiteta ovog poslovanja pretpostavlja ponovno uspostavljanje četiri osnovne slobode slobodu kretanja ljudi, robe, usluga i kapitala, koje su u novonastalim okolnostima bile u izvesnoj meri ograničene, ako ne i suspendovane. Da bi se navedeni plan ostvario, po svoj prilici biće potrebno izvršiti deregulaciju, odnosno smanivanje regulatornih opterećenja, kao i pojednostavljivanje pravila o tržišnom poslovanju. Normalno funkcionisanje jedinstvenog tržišta dalje će zahtevati produbljivanje ekonomske unije i očuvanje stabilnosti postojećeg ekonomskog poretka. ${ }^{8}$ Njegova revitalizacija i prilagođavanje u skladu nastalim klimatskim, socijalnim, ekonomskim i tehnološkim promenama neće biti moguća bez sveobuhvatnih i strukturalnih promena.

Delujući u tom pravcu, Evropska unija je usvojila dve važne inicijative „Evropski zeleni dogovor“ (European Green Deal) i „Sledeću generaciju Evropske unije"(Next Generation EU), kojima se na dugoročnom planu predviđaju sistemske mere integracije i transforomacije evropske privrede $u$ „zelenu i

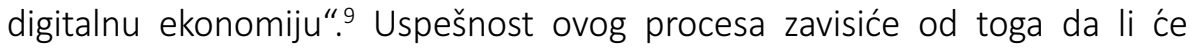
preusmeravanje evropske ekonomske politike ostati prioritet Evropske unije, uprkos vanrednoj situaciji izazvanoj zdravstvenom i ekonomskom krizom. Potom, da li će za ostvarenje navedenih programa biti obezbeđena adekvatna finansijska

\footnotetext{
8 "Communication from the Commission to the European Parliament, the Council, the European Economic and Social Committee and the Committee of the Regions - Long Term Action Plan for Better Implementation and Enforcement of Single Market Rules", European Commission, Bussels, 10.03.2020, COM(2020) 94 final.

${ }^{9}$ Radeći progresivno na realizaciji zacrtanih ciljeva u navedenim inicijativama, ministri država članica Evropske unije, na sastanku održanom 19. marta 2021. godine, potpisali su tri političke deklaracije kako bi udružili napore i resurse za promociju međunarodne povezanosti, uvođenje čistih digitalnih tehnologija i poboljšanje regulatornog okruženja. Deklaracijama koje se odnose na evropske pristupne mreže, EU Startup Nations standard i zelenu i digitalnu transformaciju Evropske unije, potvrđuje se želja država članica za ubrzanjem preoblikovanja evropske privrede u zelenu i digitalnu ekonomiju koja bi doprinela očuvanju zdrave životne sredine. Videti: "Digital Day 2021: EU countries commit to key digital initiatives for Europe's Digital Decade", EUreporter, 22 March 2021, Internet: https://www.eureporter.co/business/digital-technology/2021/03/22/digital-day-2021-eucountries-commit-to-key-digital-initiatives-for-europes-digital-decade/, 01/07/2021.
} 
sredstva iz različitih javnih i privatnih izvora kako bi se evropska privreda preusmerila u pravcu korišćenja obnovljivih izvora energije uz znatno viši stepen energetske efikasnosti. Konačno, koordinirana realizacija inicijativa - „Evropskog zelenog dogovora" i "Sledeće generacije Evropske unije“ zavisiće i od normativnog upodobljavanja nadležnosti institucija Evropske unije, kao i od unapređenja međunarodne saradnje na planu postizanja klimatske neutralnosti i prelaska na tehnološki naprednije oblike „zelenog industrijskog privređivanja“.10

\section{Evopski zeleni dogovor}

„Evropski zeleni dogovor" suštinski predstavlja skup različitih političkih inicijativa koje je Komisija Evropske unije u formi Saopštenja podnela Evropskom parlamentu, Evropskom savetu, Evropskom ekonomskom i socijalnom odboru i Odboru regiona u decembru 2019. godine..$^{11}$ Inicijativama se predviđa nova strategija održivog rasta kojom bi Evropska unija bila transformisana u pravedno i prosperitetno društvo sa modernom, efikasnom i konkurentnom privredom. Ova tranzicija koja bi trebalo da bude pravedna i inkluzivna pretpostavlja očuvanje i povećanje prirodnih resursa Evropske unije uz zaštitu zdravlja i dobrobiti građana od rizika povezanih sa životnom sredinom kao što su klimatske promene, gubitak biodiverziteta, oštećenje ozonskog omotača, zagađenje vazduha, vode i zemljišta, izazivanje urbanih stresova i dr. ${ }^{12}$ "Evropski zeleni dogovor" predstavlja deo šire Agende Ujedinjenih nacija o održivom razvoju do 2030. godine. ${ }^{13}$ Njegovim

\footnotetext{
${ }^{10}$ Marco Siddi, "The European Green Deal - Assesing its current state and future implementation", FIIA Working Paper, 2020, no. 114, pp. 4-11.

11 "Communication from the Commission to the European Parliament, the European Council, the Council, the European Economic and Social Committee and the Committee of the Regions - the European Green Deal", European Commission, Bussels, 11.12.2019, COM 2019/640 final.

12 Što se tiče klimatskih promena, predviđa se da će se nivo ugljen-dioksida (CO2), biti udvostručen do 2030. godine sa očekivanim porastom temperature u Evropi za $2-3^{\circ} \mathrm{Cu}$ letnjoj sezoni. Prema relevantnim procenama, Evropa je odgovorna za skoro jednu trećinu svetske emisije gasova koje iscrpljuju Zemljin ozonski omotač. Videti: "Problems", European Environment Agency, 20 April 2016, Internet: https://www.eea.europa.eu/publications/ 92-827-5122-8/page014.html, 01/07/2021.

${ }^{13}$ Transforming our world: the 2030 Agenda for Sustainable Development, United Nations General Assembly, A/RES/70/1, 21 October 2015.
} 
smernicama usmerava se proces makroekonomske koordinacije, donošenja politika i delovanja Evropske unije u okviru ciljeva održivog razvoja svetske organizacije. Ciljevima se planira smanjenje emisije gasova staklene bašte za najmanje $50-55 \%$ do 2030. godine, kao i njegova eliminacija do 2050. godine revidiranjem fiskalnog, regulatornog i trgovinskog režima. ${ }^{14}$ Realizacijom navedenih ciljeva, Evropa bi postala prvi „,klimatski neutralan kontinent“. ${ }^{15}$ Pošto ciljeve „Evropskog zelenog dogovora“ nije moguće ostvariti bez pravne regulacije, Evropska unija je već u prvoj polovini 2020. godine, donela odgovarajući pravni okvir o klimi (Europen Climate Law), kojim se na zakonodavnom planu utvrđuju navedeni ciljevi. ${ }^{16} \mathrm{Uz}$ naknadno preispitivanje i revidiranje relevantnih pravnih i političkih instrumenta povezanih sa emisijom gasova staklene bašte, Evropska unija se obavezala i da izradi efikasniju evropsku strategiju o klimatskim promenama koja bi bila prilagođena Okvirnoj konvenciji Ujedinjenih nacija o promeni klime iz 2015. godine (tzv. Pariskom sporazumu). ${ }^{17} \mathrm{~S}$ tim u vezi, Evropska unija namerava da dodatnim merama preusmeri postojeće ekonomske politike u pravcu postizanja „održive budućnosti“, koja prema „Evropskom zelenom dogovoru", pretpostavlja redefinisanje svih politika koje u praksi obuhvataju snabdevanja čistom energijom (Clean Energy).

\footnotetext{
${ }^{14}$ Hosuk Lee-Makiyama, "The EU Green Deal and Its Industrial and Political Significance", ECIPE Policy Brief, 2021, no. 1, pp. 1-10.

${ }^{15}$ Ursula von der Leyen, Political guidelines for the next Commission (2019-2024) - 'A Union that strives for more: My agenda for Europe', Publications Office of the European Union, 2019, Internet: http://www.eunec.eu/sites/www.eunec.eu/files/attachment/files/ political-guidelines-next-commission_en_kopie.pdf, 01/07/2021. "Communication from the Commission to the European Parliament, the European Council, the Council, the European Economic and Social Committee, the Committee of the Regions and the European Investment Bank - A Clean Planet for all - A European strategic long-term vision for a prosperous, modern, competitive and climate neutral economy", European Commission, Bussels, 28.11.2018, COM (2018) 773 final.

16 "Proposal for a Regulation of the European Parliament and of the Council establishing the framework for achieving climate neutrality and amending Regulation (EU) 2018/1999 (European Climate Law)", European Commission, Bussels, 4.3.2020, COM (2020) 80 final.

17 "United Nations Framework Convention on Climate Change (UNFCCC)", Paris Agreement, FCCC/CP/2015/L.9, Internet: https://unfccc.int/resource/docs/2015/cop21/eng/l09r01.pdf
} 


\section{Politika čiste energije}

Budući da je klimatska neutralnost do 2050. godine glavni cilj „Evropskog zelenog dogovora", preispitivanje politike čiste energije uključuje sve industrijske, proizvodne, potrošačke politike, politike koje se odnose na infrastrukturu, transport, hranu, poljoprivredu i građevinarstvo, kao i fiskalna i socijalna davanja. ${ }^{18}$ Sva navedena područja delovanja Evropske unije međusobno su povezana i isprepletana, a za poboljšanje njihove efikasnosti potrebana je obnova prirodnih ekosistema, zaštita zdravlja stanovništva i održiva upotreba prirodnih resursa. Transformacija energetske politike Evropske unije podrazumeva promene u potrošačkim i poslovnim praksama koje treba da omoguće održiva javna i privatna ulaganja. Različiti instrumenti određivanja cena energije stoga će morati da se međusobno nadopunjavaju, a revizija i usklađivanje fiskalnog okvira o njihovom oporezivanju vršiće se u skladu sa ciljevima na području zauzdavanja klimatskih promena. ${ }^{19}$ Da bi se napravio kompromis između ekonomskih i socijalnih potreba, Evropska unija se obavezala da vodi računa o rešenjima koja bi bila najkorisnija za očuvanje zdrave životne sredine. Tim pre, jer proizvodnja i upotreba energije u različitim ekonomskim sektorima predstavlja trenutno izvor više od 75 procenata emisija gasova staklene bašte u Evropskoj uniji. Preorijentacija evropske ekonomije na efikasnije i obnovljive izvore energije, uz postepeno ukidanje upotrebe uglja i dekarbonizaciju gasa, sledstveno pretpostavlja potpunu integraciju i međuzavisnost evropskog energetskog tržišta. ${ }^{20}$ Za postizanje navedene tranzicije, polaznu osnovu predstavljaće strategija Evropske unije o integraciji energetskog sistema. ${ }^{21} \mathrm{Uz}$ sprovođenje ovog strateškog dokumenta, države članice imaju još i obavezu da do 2023. godine,

\footnotetext{
${ }^{18}$ Carlo Jaeger, Jahel Mielke, Franziska Schütze, Jonas Teitge, Sarah Wolf, "The European Green Deal - More Than Climate Neutrality", Intereconomics Review of European Economic Policy, 2021, vol. 56, no. 2, pp. 99-107.

19 "Council Directive 2003/96/EC of 27 October 2003 restructuring the Community framework for the taxation of energy products and electricity", OJ L 283, 31.10.2003, pp. 51-70.

${ }^{20}$ Jeremy Rifkin, The Green New Deal: Why the Fossil Fuel Civilization Will Collapse by 2028, and the Bold Economic Plan to Save Life on Earth, St. Martin's Press, New York, 2019, p. 280.

21 "Communication from the Commission to the European Parliament, the Council, the European Economic and Social Committee and the Committee of the Regions Powering a Climate-Neutral Economy: An Eu Strategy for Energy System Integration", European Commission, Bussels, 8.07.2020, COM(2020) 299 final, pp. 1-21.
} 
ažuriraju svoje klimatske i nacionalne energetske planove kako bi ostvarile planirane ciljeve do 2030. godine (na primer, sprovođenjem mera elektrifikacije ili razvoja čistih goriva, uključujući i vodonik). ${ }^{22}$ Imajući u vidu da će podsticanje digitalizacije imati značajnu ulogu na ovom planu, Evropska unija se zalaže za suštinske promene koje bi omogućile delotvornije delovanje evropskog energetskog sistema u celini. ${ }^{23}$

\section{Politika održive industrije}

Drugo ciljno područje „Evropskog zelenog dogovora“ jeste sprovođenje plana kružne ekonomije. Ciljevi kružne ekonomije sadržani su u industrijskoj strategiji koju je Evropska unija usvojila u martu 2020. godine. Uzimajući ogroman gubitak biodiverziteta, počev od sedamdesetih godina prošlog veka (čak 90 procenata), Evropska unija se opredelila da kroz realizaciju kružne ekonomije podstakne rast vodećih tržišta za klimatski neutralne i kružno održive proizvode. lako će akcijski plan za kružnu ekonomiju služiti za tranziciju svih industrijskih sektora, Evropska unija namerava da svoje delovanje posebno usmeri na resursno intenzivne sektore, kao što su tekstilni sektor, građevinarstvo, elektronski sektor i industriju plastike. Za energetski intenzivne industrije, kao što su industrija čelika, hemijska industrija i proizvodnja cementa, Evropska unija predviđa ubrzanu dekarbonizaciju uz uvođenje modernih tehnoloških procesa sa nultom emisijom gasova staklene bašte. Uz podsticanje novih oblika

\footnotetext{
22 "Communication from the Commission to the European Parliament, the Council, the European Economic and Social Committee and the Committee of the Regions a Hydrogen Strategy for a Climate-Neutral Europe", European Commission, Bussels, 8.07.2020, pp. 123; Christopher Jones, Andris Piebalgs, Jean-Michel Glachant, "Energy Priorities for the Von der Leyen Commission", Robert Schuman Centre, Policy Brief, 2019, no. 16, pp. 1-11.

23 "Regulation (EU) 2018/1999 of the European Parliament and of the Council of 11 December 2018 on the Governance of the Energy Union and Climate Action, amending Regulations (EC) No 663/2009 and (EC) No 715/2009 of the European Parliament and of the Council, Directives 94/22/EC, 98/70/EC, 2009/31/EC, 2009/73/EC, 2010/31/EU, 2012/27/EU and 2013/30/EU of the European Parliament and of the Council, Council Directives 2009/119/EC and (EU) 2015/652 and repealing Regulation (EU) No 525/2013 of the European Parliament and of the Council", OJ L 328, 21.12.2018, pp. 1-77; "Proposal for a Regulation of the European Parliament and of the Council on guidelines for transEuropean energy infrastructure and repealing Regulation (EU) No 347/2013", European Commission, Bussels, 15.12.2020, COM/2020/824 final.
} 
industrijske saradnje i finansijska ulaganja u strateške lance vrednosti (kroz podsticanje državnih javnih i privatnih investicija), Evropska unija će nastojati da podstakne istraživačke i inovacione delatnosti u različitim sektorima kružne ekonomije. Takođe, Unija će se zalagati za finansiranje ciljeva „Evropskog zelenog dogovora" kroz investicioni plan - InvestEU, koji predviđa najmanje milijardu evra investicija. Prema nekim preliminarnim procenama, Evropska unija bi trebalo da do 2030. godine investira približno 260 milijardi evra u realizaciju planiranih ciljeva.

\section{Politika obnove i izgradnje}

Ova politika fokusira se na preispitivanje energetski efikasnih metoda obnove i izgradnje zgrada. Pošto postojeće energetske performanse zgrada nisu zadovoljavajuće (čak 40 procenata potrošene energije odlazi za javne i privatne zgrade), smatra se da je potrebno udvostručiti sredstva kako bi se ostvarili ciljevi Evropske unije u pogledu energetske efikasnosti (što bi značilo i do 2,4 procenta ulaganja iz evropskog budžeta). Poseban probem u realizaciji ovog cilja predstavlja pristupačnost cena. Obrazloženje za preispitivanje politike obnove i izgradnje zgrada nalazi se u opravdanju da bi ovim procesom došlo generalno da smanjivanja računa za utrošak energije, što bi u krajnjem slučaju smanjilo i energetsko siromaštvo. U prilog navedenom ističe se i podupiranje građevinskog sektora i aktivnosti malih i srednjih preduzeća, čime bi nacionalni prihodi bili povećani, a to bi omogućilo dodatnu obnovu socijalnih stanova, škola i bolnica. Realizacija ove inicijative u okviru „Evropskog zelenog dogovora" obuhvata i inovativne programe finansiranja u okviru fonda InvestEU.

\section{Politika održive mobilnosti}

Smanjenje emisija gasova staklene bašte iz saobraćaja i transporta, na koju se odnosi čak 25 procenata od ukupne emisije gasova sa efektom staklene bašte, predstavlja takođe jedan od ciljeva u okviru "Evropskog zelenog dogovora". Naime, smatra se da je potrebno smanjiti ovu emisiju čak do 90 procenata do 2050. godine kako bi se postigao cilj klimatske neutralnosti. Prema planu, svi vidovi saobraćaja će morati dati doprinos ostvarenju ovog cilja. Krajnjim korisnicima transportnih usluga moraće se na tom planu staviti na raspolaganje jeftiniji, pristupačniji, dostupniji, zdraviji načini transporta sa niskim emisijama 
gasova. Novi i održivi načini transporta uključuju uvođenje drugačijih goriva sa niskim ili nultim emisijama CO2, koja bi predstavljala alterantivu trenutnim gorivima. Razvoj različitih sredstava transporta i načina mobilnosti, značilo bi i izmenu postojećeg regulativnog okvira. Evropska komisija je na tom planu, u decembru 2020. godine, donela važno Saopštenje koji sadrži sveobuhvatnu strategiju o „održivoj i pamentoj mobilnosti“. ${ }^{24}$ Kroz nju se nastoje rešiti pitanja najvećih izvora zagađenja u saobraćaju, kroz davanje podsticaja različitim oblicima multimodalnog prevoza. ${ }^{25}$

\section{Prehrambena politika}

Preoblikovanje prehrambene industrije predstavlja jedan od najznačajnih ciljeva „Evropskog zelenog dogovora“. Naime, od razvoja ove grane industrije zavisi ishrana svetskog stanovništva, a što samo po sebi predstavlja veliki izazov za postojeće obrasce proizvodnje. Proizvodnja hrane i dalje uzrokuje zagađenje vazduha, vode i zemljišta, pridonosi gubitku biološke raznolikosti i klimatskim promenama budući da se njome troše prekomerne količine prirodnih resursa. Transformacija prehrambene industrije predstavlja otud imperativ za Evropsku uniju, jer se uvođenjem novih tehnologija i naučnih otkrića povećava uloga svih subjekata u lancima vrednosti „održivih“ prehrambenih proizvoda. Evropska komisija je u maju 2020. godine, predstavila Saopštenje u kojem je sadržana strategija „od farme do viljuške“ (From Farm to Fork), kojom se na široj ravni raspravlja o pitanjima „održivosti hrane" i podršci koju valja dodeliti prehrambenim proizvođačima (poljoprivrednicima i ribarima). ${ }^{26}$ Evropska unija

24 "Communication from the Commission to the European Parliament, the Council, the European Economic and Social Committee and the Committee of the Regions Sustainable and Smart Mobility Strategy - Putting European Transport on Track for the Future", European Commission, Bussels, 9.12.2020, COM(2020) 789 final.

${ }^{25} \mathrm{U}$ tom smislu, Evropska komisija se obavezala da povuče predlog za reviziju Direktive o multimodalnom transportu robe. Videti: "Proposal for a Directive of the European Parliament and of the Council Amending Directive 92/106/EEC on the Establishment Of Common Rules for Certain Types of Combined Transport of Goods between Member States", European Commission, Bussels, 15.12.2017, COM(2017) 648 final.

26 "Communication from the Commission to the European Parliament, the Council, the European Economic and Social Committee and the Committee of the Regions a Farm to Fork Strategy For a Fair, Healthy and Environmentally-Friendly Food System", European Commission, Bussels, 20.05.2020, COM/2020/381 final. 
planira da blisko sarađuje sa državama članicama u vezi poboljšanja nacionalnih strateških poljoprivrednih planova koji bi morali odražavati ambicije „Evropskog zelenog dogovora". Nacionalni poljoprivredni planovi trebalo bi otud da budu jedan od činilaca koji će dovesti do boljih i održivijih praksi u oblastima kao što su precizna poljoprivreda, ekološka poljoprivreda, agroekologija, agrošumarstvo i dobrobit životinja. Evropska unija će nastojati da svoju prehrambenu politiku usmeri u pravcu podsticanja regenerativne poljoprivredne proizvodnje primenom novih tehnologija koje doprinose zaštiti životne sredine, odnosno poboljšanju biodiverziteta i kvaliteta vode, zemljišta i vazduha. ${ }^{27}$ To će inter alia značiti i bolje pohranjivanje i kontrolu $\mathrm{CO} 2$, smanjenje upotrebe veštačkih đubriva (za 20 procenata), pesticide (za 50 procenata) i antimikrobnih sredstava u akvakulturi i poljoprivredi (za 50 procenata), povećanje proizvodnje zdrave organske hrane (uz smanjenje gubitka hranljivih sastojaka za najmanje 50 procenata), uz racionalno iskorišćavanje dostupnog poljoprivrednog zemljišta što, „na kraju krajeva“, sve treba da doprinese dobrobiti stanovništva i ostvarivanju ciljeva održive kružne ekonomije do 2030. godine. ${ }^{28}$

\section{Politika zaštite životne sredine i biološke raznovrsnosti}

U zacrtanim ciljevima „Evropskog zelenog dogovora“, zaštita životne sredine i biološke raznovrsnosti predstavlja jedan od prioriteta. Namera Evropske unije za sprečavanjem i uklanjanjem zagađenja vazduha, vode i zemljišta iz „svih izvora" do 2050. godine potvrđena je u Saopštenju Evropske komisije iz maja 2021. godine. ${ }^{29}$ Navedeni akt sadrži „Akcioni plan nultog zagađenja“, kojim se

\footnotetext{
${ }^{27}$ Naučnici koji se bave ekologijom smatraju da bez zaštite i obnove tla na 4 milijarde hektara obrađenog poljoprivrednog zemljišta, 8 milijardi hektara pašnjaka i 10 milijardi hektara šumskog zemljišta, neće biti moguće prehraniti svet, zadržati globalno zagrevanje ispod 2 stepena C ili zaustaviti gubitak biodiverziteta. Videti: Ronnie Cummins, Grassroots Rising: A Call to Action on Climate, Farming, Food, and a Green New Deal, Chelsea Green Publishing, Vermont, 2020, p. 208.

28 "From Farm to Fork - our Food, our Health, our Planet, our Future", European Commission, Internet: https://ec.europa.eu/info/strategy/priorities-2019-2024/europeangreen-deal/actions-being-taken-eu/farm-fork_en, 01/07/2021.

29 "Communication from the Commission to the European Parliament, the Council, the European Economic And Social Committee and the Committee of the Regions Pathway to a Healthy Planet For All EU Action Plan: 'Towards Zero Pollution for Air, Water and Soil'", European Commission, Bussels, 12.05,2021, COM/2021/400 final.
} 
potvrđuje obaveza država članica da primene standarde o kvalitetu životne sredine u svim industrijskim delatnostima na način da životna sredina bude okruženje bez otrovnih materija. Ovim Akcionim planom Evropska unija je prihvatila sa obnovljenom odlučnošću potrebu da se krene ka čistom i kružnom ekonomskom modelu zasnovanom na obnovljenim i zdravim prirodnim ekosistemima. U skladu sa „Evropskim zelenim dogovorom“, Akcioni plan dalje razrađuje viziju sveta bez zagađenja i kombinuju sve tekuće i planirane napore $\mathrm{u}$ integrisanu strategiju koja prevenciju zagađenja stavlja na prvo mesto. S obzirom na to da su mnoge aktivnosti na realizaciji ovih ciljeva u toku, ili tek počinju da donose rezultate, Komisija Evropske unije odlučila je da do 2025. godine izvrši analizu stepena primene ovog Akcionog plana. U realizaciji ciljeva očuvanja i obnove ekosistema iz „Evropskog zelenog dogovora“, Evropska unija je identifikovala niz problema vezanih za smanjenje biološke raznovrsnosti. U Saopštenju Evropske komisije donete u maju 2020. godine, koje sadrži strategiju biodiverziteta za 2030. godinu, Evropska unija predstavila je niz ciljeva poput proširenja zaštite kopnenih i morskih područja sa bogatom biološkom raznolikošću. ${ }^{30}$ Poseban naglasak je pri tome stavljen na gazdovanje šumama koje bi trebalo zaštititi i obnoviti do 30 procenata do 2030. godine. $U$ istoj srazmeri predviđa se i obnavljanje morskih područja koja bi trebala da postanu glavni oslonac za stvaranje „održive plave ekonomije“, koja bi preuzela središnju ulogu u smanjenju iskorištavanja zemljišnih resursa Evropske unije i borbi protiv globalnih klimatskih promena. Polazeći od potrebe proširenja prekogranične saradnje država članica, Evropska unija je istakla finansijsku delotvornost uspostavljene mreže Natura 2000, kroz koju države mogu sprovesti mere za unapređenje i obnovu oštećenih ekosistema. S obzirom na to da je strategija biodiverziteta suštinski deo strategije ublažavanja klimatskih promena, Evropska unija predviđa da se od ukupno 25 procenata evropskog budžeta namenjenog za borbu protiv klimatskih promena, značajan deo izdvoji i za obnavljanje biodiverziteta i postizanje rešenja zasnovanih na prirodi. ${ }^{31}$

30 "Communication from the Commission to the European Parliament, the Council, the European Economic and Social Committee and the Committee of the Regions EU Biodiversity Strategy for 2030 Bringing Nature Back Into Our Lives", European Commission, Bussels, 20.05.2020, COM/2020/380 final.

${ }^{31}$ Prema analizama, čak 40 milijardi evra prihoda u Evropskoj uniji zavisi od prirode i njenih resursa. Videti: "Factsheet: EU 2030 Biodiversity Strategy", European Commission. 20 May 2020, Internet: https://ec.europa.eu/commission/presscorner/detail/en/fs_20_906, 01/07/2021. 


\section{Evropski plan oporavka nakon pandemije KOVID 19}

Iz prethodnih izlaganja može se primetiti da je od izbijanja pandemije Kovid 19 2020. godine, Evropska unija u fokus svojih strateških razmatranja oko transformacije postojećeg ekonomskog sistema, uvrstila i pitanja postizanja održivog ekonomskog rasta zasnovanog na zelenoj ekonomiji i digitalizaciji. Postepenom eskalacijom zdravstvene krize došlo je, međutim, do slabljenja entuzijamzma u vezi sprovođenja dugoročnih ciljeva predviđenih $u$ „Evropskom zelenom dogovoru“. Neke države članice Evropske unije poput Poljske, Rumunije, Bugarske, Mađarske i Češke, čije industrije uglavnom zavise od uglja ili nuklearne energije, predložile su godišnju pauzu ili čak i ukidanje „Evropskog zelenog dogovora". Smatrajući da bi u fokus procesa redefinisanja politika Evropske unije trebalo staviti pre svega saniranje posledica zdravstvene i ekonomske krize, ove države su izrazile neslaganja u vezi planiranih ciljeva i vremenskog okvira za njihovo postizanje. $U$ odsustvu striktnih obaveza u nacionalnim energetskim i klimatskim politikama, ovakvi predlozi nisu dobili većinu u Evropskoj uniji. Evropska unija je, naime, ostala dosledna u sprovođenju planiranih ciljeva uspostavljanja održive i klimatske neutralne ekonomije. ${ }^{32} \mathrm{Na}$ to, uostalom, ukazuju i događaji nakon usvajanju „Evropskog zelenog dogovora“. Naime, već u aprilu 2020. godine Evropski parlament pozvao je države članice na uključivanje „Evropskog zelenog dogovora", u program ekonomskog oporavka. U tom smislu predložen je i finansijski paket za podršku evropskoj privredi nakon završetka zdravstvene krize, uključujući izdavanje obveznica koje bi trebale biti pokrivene budžetskim sredstvima. Smatralo se, naime, da bi zajednički odgovor na Kovid 19 morao biti vođen solidarnošću, kohezijom i kovergencijom, te da u tom smislu ulaganja u evropski ekonomski oporavak zahteva ustanovljavanje Fonda solidarnosti od najmanje 50 milijardi evra. Kako su vremenom rasli strahovi od mogućih negativnih posledica pandemijske krize, Evropska unija je naglašavala potrebu za sprovođenjem „Evropskog zelenog dogovora“. Najpre je to učininjeno prilikom usvajanja Strategije o biodiverzitetu, da bi potom bilo i potvrđeno

\footnotetext{
${ }^{32}$ Milan Elkerbout, Christian Egenhofer, Jorge Núñez Ferrer, Mihnea Catuti, Irina Kustova, Vasileios Rizos, The European Green Deal after Corona: Implications for EU climate policy, CEPS, Bussels, 2020, p. 2, etc.; Alister Doyle, "Four more EU nations back a green postcoronavirus recovery", Climate Home News, 20 April 2020, Internet: https://www.climate changenews.com/2020/04/20/four-eu-nations-back-green-post-coronavirus-recovery/, 01/07/2021.
} 
usvajanjem plana oporavka "Sledeća generacija Evropske unije“ (Next Generation EU) i odobravanjem budžeta od jedne hiljade milijardi evra. ${ }^{33}$ Sa ovim instrumentima, „Evropski zeleni dogovor", postao je deo šire strategije obnove Evropske unije za koju su opredeljena konkretna finansijska sredstva. ${ }^{34}$

\section{Plan „Sledeća generacija Evropske unije"}

Plan oporavka - „Sledeća generacija Evropske unije“ - predložen od strane Komisije Evropske unije u formi Saopštenja usvojen je u maju 2020. godine. ${ }^{35} \mathrm{Za}$ njegovu namenu izdvojeno je čak 750 milijardi evra iz budžeta Evropske unije. Planirana sredstva za ekonomski oporavak trebalo bi obezbediti kroz podizanje gornje granice BDP-a država članica Evropske unije za 2\%. ${ }^{36}$ Navedenim načinom, Evropska unija bi mogla iskoristi svoj kreditni rejting za prikupljanje i plasiranje sredstava na različitim finansijskim tržištima za projekte koji ispunjavaju tzv. zelene kriterijume. ${ }^{37}$ Ovi kriterijumi pretpostavljaju usmeravanje sredstava za ubrzanje zelene i digitalne tranzicije i za izgradnju prosperitetnijeg i otpornijeg

${ }^{33}$ Jack Parrock, Shona Murray, Joanna Gill,"EU coronavirus recovery package is massive shift for bloc that will work 'wonders'", Euronews, 28 May 2020, Internet: https://www.euro news.com/2020/05/28/eu-coronavirus-recovery-package-is-massive-shift-for-bloc-thatwill-work-wonders, 01/07/2021. Komisije Evropske unije predložila je da se za period od 2021. do 2026. godine, obnovi budžetski proračun na iznos cirka 1,1 hiljadu milijardi evra.

34 "Europen Green Deal", Wikipedia, Internet: https://en.wikipedia.org/wiki/European_ Green_Deal, 01/07/2021.

35 "Communication from the Commission to the European Parliament, the European Council, the Council, the European Economic and Social Committe and the Committee of the Regions Europe's Moment: Repair and Prepare for the Next Generation, European Commission", Bussels, 27.05.2020, COM/2020/456 final.

${ }^{36}$ Ovakva odluka je usledila nakon izmene Odluke EU o sopstvenim izvorima koji su predviđali izdvajanja od 1,2 procenata BDP-a. Videti: "Proposal for a Council Decision on The System of Own Resources of the European Union", European Commission", Bussels, 2.05.2018, $\operatorname{COM}(2018) 325$ final.

${ }^{37}$ Tako, na primer, $25 \%$ od od ukupnog iznosa opredeljenih sredstava trebalo bi da ode na ublažavanje klimatskih promena. Fosilna goriva i nuklearna energija bili bi isključeni iz finansiranja, a deo sredstava namenjenih ekonomskom oporavku nakon pandemije trebalo bi dodeliti obnavljanju ekonomske ravnoteže između bogatih i siromašnih zemalja Evropske unije. Videti: Frédéric Simon, "Do no harm': EU recovery fund has green strings attached", Euractiv, 27 May 2020, Internet: https://www.euractiv.com/section/energy-environment/ news/do-no-harm-eu-recovery-fund-has-green-strings-attached/, 01/07/2021. 
društva. Raspodela opredeljenih finansijskih sredstava od 750 milijardi evra (od ukupno planiranih 1,8 biliona evra), trebalo bi da se vrši u tri odvojena stuba, od čega bi 500 milijardi evra bilo raspodeljeno u vidu bespovratne pomoći, dok bi 250 milijardi evra bilo plasirano u formi zajmova državama članicama. Tako, u prvi stub bila bi plasirana sredstva pomoći državama članicama za sprovođenje ekonomskih reformi, odnosno za ustanovljavanje mehanizma za održiv oporavak i otpornost (Recovery and Resilience Facility - RRF), u iznosu od 560 milijardi evra. ${ }^{38}$ Same države članice osmislile bi planove za ekonomsku revitalizaciju na temelju prioriteta ulaganja i reformi utvrđenih u okviru evropskog semestra, a u skladu s nacionalnim klimatskim, energetskim i tranzicionim planovima, sporazumima o partnerstvu i operativnim programima u okviru fondova Evropske unije. ${ }^{39}$ Sa dodatnom pomoći za koheziju (Recovery Assistance for Cohesion and the Territories of Europe - REACT-EU), u iznosu od 55 milijardi evra, obezbedilo bi se finansiranje ekonomskog oporavka u skladu sa novim ključem raspodele, kojim se uzima u obzir konkretan uticaj krize na određena evropska područja. Sa ovom dodatnom pomoći, proširile bi se mere oporavka koje se sprovode u okviru investicionih inicijativa CRII (Coronavirus Response Investment Initiative) i CRII + (Coronavirus Response Investment Initiative Plus). Korišćenje namenskih sredstava kroz pomenute inicijative i dodatnu pomoć predviđeno je za period 2021-2022. godine, preko Evropskog fonda za regionalni razvoj (European Regional Development Fund), Evropskog socijalnog fonda (European Social Fund) i Fonda za evropsku pomoć najugroženijima (Fund for European Aid to the Most Deprived). Uz navedene finansijske fondove, opredeljena finansijska sredstva bila bi iskorištena i kroz druge evropske fondove i programe kao što su Horizon 2020 (Horizon 2020), Evropski poljoprivredni fond za ruralni razvoj (European Agricultural Fund for Rural Development - EAFRD) i Fond za pravedniju tranziciju (Just Transition Fund - JTM). Sredstva u iznosu od 31 milijarde evra predviđena su za finansiranje drugog stuba koji će služiti pokretanju evropske privrede. Sredstva bi trebalo obezbediti putem privatnih investicija koje bi dodatno podstakle ulaganja od još 300 milijardi evra u osiguranje solventnosti evropskih privrednih subjekata. U okviru drugog stuba predviđa se još i nadogradnja programa InvestEU, kao vodećeg evropskog programa za investicije, kao i uspostavljanje posebnog mehanizma za strateška ulaganja za koji će, prema sporazumu postignutom u Evropskom savetu, biti namenjeno 15 milijardi evra. Pomenuti mehanizam omogućio bi prikupljanje dodatnih 150 milijardi evra za jačanje otpornosti i strateške autonomije u svim ključnim tehnologijama i lancima vrednosti. U pogledu trećeg stuba, koji se 
odnosi na sticanje iskustava tokom krize, plan oporavka predviđa uspostavljanje posebnog programa EU4Health za koji su planirana sredstva od 9,4 milijardi evra. Ova sredstva trebalo bi iskoristiti za povećanje efikasnosti zdravstvene zaštite i osnaženje drugih važnih programa poput Horizon Evropa i RescEU, i drugih mehanizama koji se odnose na međunarodnu saradnju, susedstvo, humanitarnu pomoć i ekonomski razvoj..$^{40}$ Konačno, celokupan plan oporavka potvrđen je u nešto izmenjenoj sadržini paketa pomoći kroz usvajanje Uredbe Evropske unije o ustanovljavanju instrumenta oporavka nakon okončanja pandemije Kovid 19, 14. decembra 2020. godine. ${ }^{41}$ Tako su prema ovom instrument mehanizmu za oporavak (RRF) dodeljena ukupna sredstva od 672,5 milijardi evra, REACT-EU 47,5 milijardi evra, programu Horizon Evopa - 5 milijardi evra, InvestEU - 5,6 milijardi evra, Evropskom poljoprivrednom fondu za ruralni razvoj $-7,5$ milijardi evra, Fondu za pravedniju trazniciju - 10 milijardi evra i RescEU - 1,9 milijardi evra. Istovremeno sa donošenjem ovog instrumenta, kojim su preusmerena namenska sredstva iz paketa „Sledeća generacija Evropske unije“, doneta je i nova Odluka o sopstvenim resursima prema kojoj se Evropska unija ograničila da sredstva za svoj dugoročni budžet i paket oporavka bazira isključivo na carinama i doprinosima koji se temelje na PDV-u i bruto nacionalnom dohotku. ${ }^{42}$

${ }^{38} \mathrm{U}$ međuvremenu je, na osnovu sporazuma postignutog u Evropskom savetu, planirani iznos uvećan na 672,5 milijardi evra. Od tog iznosa 360 milijardi evra čine zajmovi, a 312,5 milijardi evra bespovratna sredstva. $S$ druge strane pak opredeljeni iznosi bespovratnih sredstava za druge namene znatno su umanjeni u odnosu na planirane iznose. Videti: „Europski plan oporavka“, Europska komisija, Internet: https://ec.europa.eu/info/strategy /recovery-plan-europe_hr, 01/07/2021.

39 "Regulation (EU) 2021/241 of the European Parliament and of the Council of 12 February 2021 establishing the Recovery and Resilience Facility", OJ L, 57, 18.12.2021, pp. 17-75.

${ }^{40}$ Komisija Evropske unije ujedno smatra da bi valjalo podstaći i druge značajne instrumente, fondove i programe poput Programa za jedinstveno tržište, potom Evropski fond za pomorstvo i ribarstvo, program pomoći saradnji u oblasti poreza i carina, instrument za povezivanje Evrope, Erasmust, program Kreativna Evropa, program Digitalna Evropa, Evropski fond za odbranu, Fond za unutarnju bezbednost, Fond za azil i migracije, Fond za integrisano upravljanje granicama i predpristupnu pomoć.

41 "Council Regulation (EU) 2020/2094 of 14 December 2020 establishing a European Union Recovery Instrument to support the recovery in the aftermath of the COVID-19 crisis", OJ L, 433I, 22.12.2020, pp. 23-27.

42 "Council Decision (EU, Euratom) 2020/2053 of 14 December 2020 on the system of own resources of the European Union and repealing Decision 2014/335/EU, Euratom", OJ L, 424, 15.12.2020, pp. 1-10. 
Zbog pandemije Kovid 19, predviđeno je i da Evopska unija može „pozajmiti sredstva na tržištima kapitala do 750 milijardi evra prema cenama iz 2018.,", dok bilo koji pozajmljeni iznos nije dozvoljeno koristiti za njene operativne izdatke i troškove. Takođe, predviđeno je i da Evropska komisija izdaje obveznice za finansiranje zajmova Evropske unije i trećih zemalja, a u okviru programa koji uključuje do 100 milijardi evra za program očuvanja radnih mesta (SURE). Uz to, do 2026. godine predviđa se i akumuliranje 800 milijardi evra u tekućim cenama za program oporavka "Sledeća generacija Evropske unije“, kroz diverzifikacionu strategiju finansiranja i izdvajanja od 5\% evropskog BDP-a.

\section{Zaključna razmatranja}

Izbijanjem pandemije Kovid 19 opasnost od erozije i fragmentacije međunarodnog ekonomskog poretka znatno je povećana. S obzirom na to da pandemijska kriza ne poznaje granice, ova opasnost postaje međunarodna realnost koja se manifestuje u nizu značajnih ekonomskih poremećaja u globalnim lancima snabdevanja, u destabilizaciji zajedničkog tržišta i u ogromnim gubicima u ključnim sektorima industrijske proizvodnje i uslužnih delatnosti. Snažan recesijski udar indukovan zdravstvenom krizom imao je za posledicu pad BDP-a i uvećanje javnog duga u popriličnom broju zemalja. Negativni pandemijski efekti postali su sve vidljiviji i na svetskom tržištu kapitala. Pogoršanje stanja u finansijskoj oblasti odrazilo se nužno i na socijalnu situaciju u svetu, što je ukazalo na nužnost hitnog i snažnijeg multilateralnog odgovora utemeljenog na jasnim i transparentnim pravilima i principima zasnovanim na solidarnosti, zajedništvu i međunarodnoj saradnji. ${ }^{33} \mathrm{Na}$ tom planu je Evropska unija, kao druga po veličini globalna ekonomija, preuzela vodeću ulogu blisko sarađujući sa Ujedinjenim nacijama, Svetskom zdravstvenom organizacijom, Međunarodnom organizacijom rada, grupacijama G20 i G7, Međunarodnim monetarnim fondom i Svetskom bankom. S obzirom na dimenzije poremećaja u sistemu međunarodnih ekonomskih odnosa, Evropska unija se prilagođavala nastaloj situaciji stalno se fokusirajući na najugroženije zemlje kojima je finansijska i svaka druga vrsta podrške bila potrebna, poput zemalja u Africi, Zapadnom Balkanu,

\footnotetext{
${ }^{43}$ Alfons Pérez, Green deals in a time of pandemics. The future will be contested now, Libros en Acción, La editorial de Ecologistas en Acción, Madrid, 2021, pp. 44, etc.
} 
Bliskom istoku i delovima Azije i Tihog okeana, Latinske Amerike i Kariba. Dajući prioritet zajedničkoj saradnji, Evropska unija je na unutrašnjem planu preuzela odlučne akcije na saniranju negativnih efekata ekonomske i zdravstvene krize usvajanjem značajnih strateških dokumenata - „Evropskog zelenog dogovora“ i "Sledeće generacije Evropske unije" kojima je predvidela mere oporavka i revitalizacije svoje privrede.

Na osnovu analize pomenutih strateških dokumenata, može se zaključiti da je Evropska unija pretvorila klimatske akcije u glavnu politiku objavljivanjem detaljne mape puta o postizanju klimatske neutralnosti do 2050. godine. Ovim akcionim planom poslat je moćan signal svetu da je „konkurentna održivost“ u osnovi evropske ekonomske agende, koja omogućava Evropskoj uniji i njenim državama članicama da postignu milenijumske ciljeve održivog razvoja Ujedinjenih nacija. ${ }^{44}$ Navedeni strateški dokumenti Evropske unije sledstveno potvrđuju da se ekonomski prosperitet i održivost životne sredine međusobno ne isključuju. Inicijative za oporavak i revitalizaciju evropske privrede u postpandemijskom periodu zavisiće od preusmeravanja evropskih ekonomskih politika u pravcu uvođenja novih, efikasnijih i legitimnijih modela održivog ekonomskog razvoja. Realizacija novih modela održivog razvoja u direktnoj je vezi sa sistemskom transforomacijom evropske privrede $u$ „zelenu i digitalnu ekonomiju". Ovaj proces sam po sebi je neizvestan i zahtevaće dodatne troškove koji će se odraziti na rast evropskog BDP-a (tačnije na njegov pad između 12,5\%). Budući da je navedeno ekonomsko preusmeravanje umnogome usložnjeno aktuelnim klimatskim, ekonomskim, socijalnim i tehnološkim promenama, Evropska unija će kroz niz političkih instrumenata, ekonomskih programa, normativno upodobljenih pravnih akata i operativnih mehanizama, te sa širokim asortimanom fondova finansijskih sredstava mobilisanih iz različitih javnih i privatnih izvora, nastojati da postigne planirane razvojne ciljeve predviđene "Evropskim zelenim dogovorom" i planom oporavka "Sledeće generacije Evropske unije" kako bi u perspektivi uspostavila socijalno pravedno, ekološki održivo i ekonomski stabilno, integrisano i prosperitetno društvo. ${ }^{45}$

44 "Communication from the Commission to the European Parliament, the Council, the European Central Bank, the European Economic and Social Committee, the Committee of the Regions and the European Investment Bank Annual Sustainable Growth Strategy 2020", European Commission, Bussels, 17.12.2019, COM/2019/650 final.

${ }^{45}$ Alicja Sikora, "European Green Deal - legal and financial challenges of the climate change", ERA Forum, 2021, no. 21, pp. 681-697; Ruven Fleming, Romain Mauger, "Green and Just? 


\section{Literatura}

Cummins, Ronnie, Grassroots Rising: A Call to Action on Climate, Farming, Food, and a Green New Deal, Chelsea Green Publishing, Vermont, 2020.

De Witte, Bruno, “The European Union's COVID-19 recovery plan: The legal engineering of an economic policy shift", Common Market Law Review, 2021, vol. 58, no. 3.

Dimitrijević, Duško, „Uredba Evropskog parlamenta i Saveta o uspostavljanju okvira za proveru stranih direktnih investicija u Evropskoj uniji", Evropsko zakonodavstvo, 2019, vol. 18, br. 68.

Elkerbout, Milan Egenhofer, Christian, Ferrer, Jorge Núñez, Catuti, Mihnea, Kustova, Irina, Rizos, Vasileios, The European Green Deal after Corona: Implications for EU climate policy, CEPS, Bussels, 2020.

Fleming, Ruven, Mauger, Romain, "Green and Just? An update on the European Green Deal", Journal for European Environmental \& Planning Law, 2021, vol. 18, no. 1-2.

Gavas, Mikaela, Pleeck, Samuel, "Global Trends in 2021: How COVID-19 is Transforming International Development", Center for Global Development Note, March 2021 "Common Framework for Debt Treatments beyond the DSSI", Paris Club.

Jaeger, Carlo, Mielke, Jahel, Schütze, Franziska, Teitge, Jonas, Wolf, Sarah, "The European Green Deal - More Than Climate Neutrality", Intereconomics Review of European Economic Policy, 2021, vol. 56, no. 2.

Jones, Christopher, Piebalgs, Andris, Glachant, Jean-Michel, "Energy Priorities for the Von der Leyen Commission", Robert Schuman Centre, Policy Brief, 2019, no. 16.

Lee-Makiyama, Hosuk, "The EU Green Deal and Its Industrial and Political Significance", ECIPE Policy Brief, 2021, no. 1.

Pérez, Alfons, Green deals in a time of pandemics. The future will be contested now, Libros en Acción, La editorial de Ecologistas en Acción, Madrid, 2021.

An update on the European Green Deal", Journal for European Environmental \& Planning Law, 2021, vol. 18, no. 1-2, pp. 164-180; Bruno De Witte, "The European Union's COVID19 recovery plan: The legal engineering of an economic policy shift", Common Market Law Review, 2021, vol. 58, no. 3, pp. 635-682. 
Rifkin, Jeremy, The Green New Deal: Why the Fossil Fuel Civilization Will Collapse by 2028, and the Bold Economic Plan to Save Life on Earth, St. Martin's Press, New York, 2019.

Siddi, Marco, "The European Green Deal - Assesing its current state and future implementation", FIIA Working Paper, 2020, no. 114.

Sikora, Alicja, "European Green Deal - legal and financial challenges of the climate change", ERA Forum, 2021, no. 21.

\section{REVERSION OF THE EUROPEAN UNION ECONOMIC POLICY AFTER THE COVID-19 PANDEMIC}

Abstract: The COVID-19 pandemic has raised fundamental questions about the legitimacy and sustainability of the current economic order of the European Union. This is all the more so because the health crisis has led to significant economic disruptions manifesting themselves in global supply chains, in the destabilization of financial markets and huge losses in key sectors of industrial production and service activities. The recession shock has led to a fall in GDP and an increase in public debt in a significant number of member states. The negative pandemic effects have become more visible in the capital market, where the European Union has introduced targeted protectionist measures to control the inflow of foreign direct investment from third countries in order to protect its own public order and security. As international trade and foreign direct investment are one of the key determinants of the development of the European economy and regional integration, it is quite logical to raise the issue of the revitalization of the European economy in the post-pandemic period. Based on the study in question, it follows that in order to recover the European economy, member states will have to take solidarity and coordinated actions that include fulfilling the goals and tasks set out in the strategic initiatives European Green Deal and Next Generation EU. According to the mentioned strategic acts which envisage the European Union's recovery program after the COVID-19 pandemic, the member states will, with the help of a range of political and legal instruments, economic mechanisms and a broad financial seek to achieve the development goals of reorienting economic policies towards the introduction of new, more efficient, sustainable and legitimate models of economic development that will take more account of climate change and environmental protection, in order to establish socially just, environmentally sustainable and economically stable, integrated and prosperous European society of "green and digital" economy.

Keywords: EU, pandemic, economic crisis, European Green Deal. 